\title{
PENINGKATAN KETERAMPILAN MENULIS PUISI MELALUI MODEL CONCEPT SENTENCE DI KELAS TINGGI
}

\author{
Abdul Salim Wahid', Arsyi Rizqia Amalia², Din Azwar Uswatun ${ }^{3}$ \\ 1,2,3Program Studi Pendidikan Guru Sekolah Dasar Universitas \\ Muhammadiyah Sukabumi \\ 1abdulsalimwahid01@gmail.com
}

\begin{abstract}
This study aims to describe the application and improvement of poetry writing skills through the concept sentence model. The method of this research is Classroom Action Research (CAR) with a research design using the Kemmis and Mc Taggart models which were carried out in two cycles. Each cycle consists of planning actions, implementing actions, observing actions and reflecting actions. The subjects of this study were grade $4 B$ students at SDN Cibeureum Hilir 5 in Sukabumi City, 28 students, consisting of 11 male students and 17 female students. This research was conducted on October 15 to October 22, 2019. The technique of data collection was done by interviews, observation, tests, and documentation. The instrument of data collection is done by interview guidelines, teacher and student observation sheets, test poetry writing skills. Data analysis techniques were carried out in descriptive quantitative techniques. The results of the observation of teacher performance in the first cycle obtained an average value of 71 and in the second cycle obtained an average value of 95 and from the first cycle to the second cycle increased by 24 points. While the results of observations of student activities in the first cycle obtained an average value of 72 and in the second cycle obtained an average value of 86 and from the first cycle to the second cycle increased by 14 points. Results Pre-cycle research writes a description of obtaining completeness of $22 \%$. Then increasing in the first cycle reached completeness $50 \%$. In the second cycle it continued to increase to reach completeness $86 \%$. The conclusion of this study shows that the poetry writing skills of class $4 B$ students increased through the application of concept sentence model.
\end{abstract}

Keywords: Concept Sentence, Poetry Writing Skills, High Class Elementary School.

\begin{abstract}
ABSTRAK
Penelitian ini bertujuan untuk mendeskripsikan penerapan dan peningkatan keterampilan menulis puisi melalui model Concept Sentence. Metode penelitian ini adalah Penelitian Tindakan Kelas (PTK) dengan desain penelitian menggunakan model Kemmis dan Mc Taggart yang dilakukan sebanyak dua siklus. Setiap siklus terdiri dari perencanaan tindakan, pelaksanaan tindakan, observasi terhadap tindakan serta refleksi tindakan. Subjek penelitian ini adalah siswa kelas 4B SDN Cibeureum Hilir 5 Kota Sukabumi sebanyak 28 siswa, terdiri dari 11 siswa laki-laki dan 17 siswi perempuan. Penelitian ini dilaksanakan pada tanggal 15 Oktober s/d
\end{abstract}


22 Oktober 2019. Teknik pengumpulan data dilakukan dengan wawancara, observasi, tes, dan dokumentasi. Instrumen pengumpulan data dilakukan dengan pedoman wawancara, lembar observasi guru dan siswa, soal tes keterampilan menulis puisi. Teknik analisis data dilakukan secara teknik kuantitatif deskriptif. Hasil observasi kinerja guru pada siklus I memperoleh nilai rata-rata 71 dan pada siklus II memperoleh nilai rata-rata 95 serta dari siklus I menuju siklus II mengalami peningkatan sebanyak 24 poin. Sedangkan hasil observasi aktivitas siswa pada siklus I memperoleh nilai rata-rata 72 dan pada siklus II memperoleh nilai rata-rata 86 serta dari siklus I menuju siklus II mengalami peningkatan sebanyak 14 poin. Hasil penelitian pra siklus menulis deskripsi memperoleh ketuntasan $22 \%$. Kemudian meningkat pada siklus I mencapai ketuntasan $50 \%$. Pada siklus II terus meningkat mencapai ketuntasan $86 \%$. Kesimpulan penelitian ini menunjukkan bahwa keterampilan menulis puisi siswa kelas 4B meningkat melalui penerapan model Concept Sentence

Kata Kunci: Concept Sentence, Keterampilan Menulis Puisi, Sekolah Dasar Kelas Tinggi

\section{A. Pendahuluan}

Pendidikan merupakan

langkah awal seseorang untuk meningkatkan kemampuan yang ada di dalam dirinya. Adapun tujuan pendidikan sekolah yaitu sebagai proses pengembangan kemampuan yang paling mendasar setiap siswa, dimana setiap siswa belajar secara aktif karena adanya dorongan dalam diri dan adanya suasana yang memberikan kemudahan bagi perkembangan dirinya secara optimal. Tujuan pendidikan nasional merupakan "perilaku yang harus dimiliki oleh setiap bangsa Indonesia dewasa setelah menempuh pendidikan Informal rumah,Pendidikan non-formal di luar sekolah dan pendidikan formal sekolah (Djadjuri, dkk 2015:12).
Pendidikan akan tercapai dengan adanya penyusunan kurikulum yang sesuai agar tujuan pembelajaran tersampaikan secara maksimal.

Menurut Undang-undang Republik Indonesia nomor 20 tahun 2003 pasal 19 tentang Pendidikan Nasional (Djadjuri, dkk 2015:12) mengemukakan bahwa "kurikulum adalah seperangkat rencana dan pengeturan mengenai tujuan, isi, dan bahan pelajaran serta cara yang digunakan sebagai pedoman penyelenggaraan kegiatan pembelajaran untuk mencapai tujuan pendidikan tertentu". Dari penjelasan di atas yaitu mengidentifikasi beberapa komponen yang ada di dalam kurikulum yaitu : 1) Kurikulum sebagai rancangan atau program pembelajaran, 2) Kurikulum memiliki 
sejumlah komponen yaitu tujuan, isi, dan bahan.

\section{Bahasa Indonesia sebagai} pengelola ilmu pengetahuan untuk memberi harapan baru bagi tumbuhnya keyakinan bangsa ini yang menjadi identitas kebangsaannya yaitu Bahasa Indonesia (Mahsun, 2014: 95). Bahasa Indonesia dijadikan sebagai mata pelajaran di seluruh tingkat sekolah, termasuk di Sekolah Dasar (SD). Bahasa Indonesia bertujuan agar siswa mempunyai kemampuan bahasa yang baik dan benar dalam berkomunikasi dengan orang lain.

Berdasarkan hasil wawancara pada guru kelas di SDN Cibeureum Hilir 5 diantaranya kekurangan dalam hal menulis kemampuan dalam menulis puisi masih rendah, hal ini dapat dilihat dari menulis puisi yang belum baik diantaranya menentukan isi dengan tema kata pertama, menentukan diksi yang tepat, serta perataan kalimat. Dari beberapa kekurangan dalam menulis siswa belum bisa menulis puisi dengan baik dan benar. Terlihat dari pra siklus yang dilakukan dengan memberikan tugas menulis puisi, dari hasil tersebut siswa belum mampu menulis puisi dengan baik. Nilai yang didapat oleh siswa secara keseluruhan didapat nilai rata-rata 63 dengan nilai tertinggi 75 dan nilai terendah 50. Kekurangan yang dialami oleh siswa yaitu kesulitan dalam kata pertama, bait yang sangat kurang, kurang dalam pengimajinasian, kesulitan dalam menentukan kata pertama, kesulitan dalam menentukan isi dan tema, dan diksi yang kurang tepat. Salah satu faktor menulis yang kurang baik yaitu guru harus memiliki kemampuan untuk memilih metode, dan model pembelajaran yang efektif dan efisien. Pada saat pembelajaran berlangsung guru menggunakan metode ceramah dan diskusi sehingga belum terlihat hasil yang signifikan

Untuk meningkatkan keterampilan menulis puisi, penulis menggunakan model pembelajaran yang menarik. Salah satunya adalah model pembelajaran Concept sentence. Dalam penelitian ini model Concept Sentence merupakan model yang sangat cocok untuk keterampilan menulis puisi yang digunakan untuk mengembangkan kata kunci menjadi beberapa kalimat atau paragraf menjadi bait-bait puisi yang indah sehingga menjadi puisi yang baik dan berbobot. 
Menurut Shoimin (2014:37). Model pembelajaran concept sentence adalah model pembelajaran yang dilakukan dengan memberikan kartu-kartu yang berisi kata kunci, kemudian kata kunci tersebut disusun menjadi beberapa kalimat dan dikembangkan menjadi paragraf. Model ini dilakukan dengan siswa dibentuk kelompok heterogen dan membuat kalimat dengan minimal empat kata kunci sesuai materi yang disajikan.

Menurut Padi (2013) puisi adalah bagian dari sastra, sastra (Sansakerta/Shastra) merupakan kata serapan dari Bahasa Sansakerta, sastra, yang berarti "teks yang mengandung intruksi" atau "pedoman", dari kata sas yang berarti "intruksi” atau "ajaran”. Dalam Bahasa Indonesia kata ini biasa digunakan untuk merujuk kepada "kesusastraan" atau sebuah jenis tulisan yang memiliki arti atau keindahan tertentu.

Menurut Wardoyo (2013: 23) mengumakakan bahwa "Puisi sebagai suatu bentuk karya sastra terdiri atas dua unsur pokok, yaitu struktur fisik dan struktur batin yang keduanya saling keterikatan yang erat sehingga membentuk totalitas makna yang utuh".
Menurut Hartoko (dalam Padi, 2013:21) bahwa: Unsur-unsur puisi terdiri dari dua unsur, yaitu unsur tematik atau unsur semantic puisi dan unsur sintaksis puisi. Unsur tematik atau unsur semantik puisi menuju kearah struktur batin, sedangkan unsur sintaksis mengarah pada struktur fisik puisi.Struktur batin adalah makna yang terkandung dalam puisi yang tidak secara langsung dapat dihayati. Struktur batin: 1)Tema, 2)Perasaan, 3)Nada dan suasana, 4)Amanat dan pesan. Struktur fisik adalah struktur yang bias kita lihat melalui bahasanya yang tampak. Struktur fisik terdiri dari: 1)Diksi, 2)Kata konkret, 3)Versifikasi, 4)Pengimajinasian, 5)Bahasa figurative atau majas, 6)Tata wajah.

Secara umum, concept sentence merupakan model pembelajaran yang diawali dengan menyampaikan kompetensi, sajian materi, pembentukan kelompok heterogen, penyajian kata kunci sesuai materi bahan ajar, dan penugasan kelompok, prosedur selanjutnya dalam pembelajaran ini adalah mempersentasikan hasil belajar secara bergantian di depan kelas. 
Menurut Huda (2014: 317) juga menjelaskan model concept sentence yakni memunculkan kegembiraan dalam belajar, mendorong dan mengembangkan proses berpikir kreatif, mendorong siswa untuk memandang sesuatu dalam pandangan yang berbeda, dan memunculkan kesadaran untuk berubah menjadi lebih baik.

Sedangkan menurut pendapat Shoimin (2014: 37) bahwa Model pembelajaran concept sentence adalah model pembelajaran yang dilakukan dengan memberikan kartukartu yang berisi kata kunci, kemudian kata kunci tersebut disusun menjadi beberapa kalimat.

Menurut Suprijono (2013: 132) menjelaskan langkah-langkah dalam menggunakan model pembelajaran concept sentence yaitu: 1)Guru menyampaikan kompetensi yang ingin dicapai, 2)Guru menyajikan materi secukupnya, 3)Guru membentuk kelompok yang anggotanya kuranglebih 4 orang secara heterogen, 4)Guru menyajikan beberapa kata kunci sesuai materi yang disajikan, 5)Tiap kelompok membuat beberapa kalimat dengan menggunakan minimal 4 kata kunci setiap bait, 6) Hasil diskusi kelompok didiskusikan kembali secara pleno yang dipandu oleh guru, 7)Kesimpulan.

Berdasarkan permasalahan yang telah diuraikan maka model pembelajaran concept sentence dapat diterapkan untuk mengatasi permasalahan menulis di sekolah dasar, dengan menerapkan model tersebut siswa diharapkan berpikir kreatif dan bekerjasama dalam kelompok sehingga menghasilkan puisi yang baik dan benar.

\section{B. Metode Penelitian}

Metode yang digunakan pada penelitian ini yaitu Penelitian Tindakan Kelas (PTK), karena penelitian dilaksanakan dengan menggunakan sebuah tindakan melalui pembelajaran. Hal ini didasarkan dengan keinginan agar keberhasilan siswa pada pembelajaran meningkat atau menjadi lebih baik dibandingkan dengan keberhasilan pada saat tidak adanya tindakan pada pembelajaran.

Dalam bahasa Inggris PTK diartikan dengan Clasroom Action Research disingkat CAR. Penelitian tindakan kelas adalah penelitian yang sumbernya dari segala masalah di kelas atau dalam istilah pembelajaran. Menurut Aqib (2016: 22). 
Adapun model penelitian yang digunakan yaitu model Kemmis dan Mc Taggart, di dalam satu siklus terdapat empat komponen seperti halnya yang dilaksanakan oleh Kurt Lewin. Model ini dikembangkan oleh ahli yang tampak masih saling berdekatan dengan model yang dipertunjukan oleh Kurt Lewin. Dikatakan seperti itu, karena pada satu siklus ada empat komponen seperti halnya yang dilaksanakan oleh Kurt Lewin. Keempat komponen tersebut meliputi perencanaan tindakan, pelaksanaan tindakan, observasi terhadap tindakan, dan refleksi tindakan (Aqib, 2011:8).

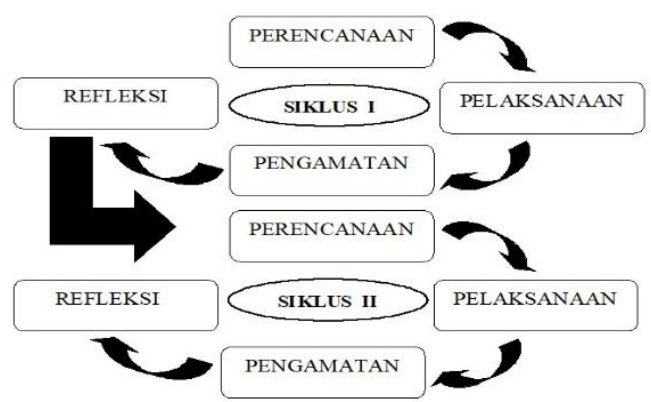

Gambar 1. Siklus PTK Model Kemmis dan MC. Taggart.

Menurut Darmadi (2015:24) menjelaskan komponen dari model Kemmis dan Mc Taggart yaitu:

1. Perencanaan Tindakan

Pada tahapan ini menjelaskan tentang apa, mengapa, kapan, di mana, oleh siapa, dan bagaimana tindakan tersebut dilakukan.

Penelitian tindakan yang ideal adalah dilakukan secara berpasangan. Dimana pada proses ini terdapat pihak yang melakukan tindakan dan pihak yang mengamati proses jalannya tindakan.

2. Pelaksanaan Tindakan

Pada tahapan ini yaitu implementasi atau penerapan isi rencana tindakan di kelas yang diteliti. Pelaksanaan tindakan ini menggunakan model Concept Sentence. Pada tahapan ini dilaksanakan di kelas 4B SDN Cibeureum Hilir 5 Sukabumi.

3. Observasi Terhadap Tindakan

Pada tahap ini menjelaskan kegiatan observasi yang dilakukan oleh pengamat (baik oleh orang lain maupun guru sendiri). Pada tahap ini peneliti memerlukan observer untuk membantu proses pelaksanaan penelitian di kelas 4B. Observer yang dibutuhkan pada proses penelitian ini yaitu berjumlah 3 orang observer.

4. Refleksi Tindakan

Pada tahap ini yaitu kegiatan untuk mengemukakan kembali apa yang sudah dilakukan. 
Refleksi tindakan ini peneliti bersama teman sejawat, guru dan dosen pembimbing. Pada tahap ini pun berdiskusi mengenai kekurangan, kelebihan penerapan model Concept Semtemce dalam pembelajaran bahasa Indonesia dengan menganalisis hasil tes kemampuan menulis puisi serta menentukan metode perbaikan selanjutnya.

\section{Partisipan Penelitian}

Partisipan penelitian ini adalah siswa kelas 4B di SDN Cibeureum Hilir 5 Sukabumi tahun pelajaran 2019/ 2020 dengan memilih seluruh siswa di dalam kelas dengan jumlah 28 siswa yang terdiri dari 11 siswa laki-laki dan 17 siswa perempuan. Alasan melakukan penelitian di kelas 4B karena mempunyai permasalahan pada mata pelajaran bahasa Indonesia pada dalam keterampilan menulis puisi yang masih rendah.

\section{Waktu dan Tempat Penelitian}

Penelitian ini dilaksanakan pada tanggal $15 \mathrm{~s} / \mathrm{d} 22$ Oktober 2019. Penelitian ini dilaksanakan di SDN Cibeureum Hilir 5 Sukabumi yang terletak di Jln.Pembangunan, Kelurahan Babakan, Kecamatan Cibeureum, Kota Sukabumi yang dilaksanakan pada semester genap tahun ajaran 2019/2020.

\section{Teknik Pengumpulan Data}

Pengumpulan data merupakan proses pengambilan terhadap suatu data lalu dikumpulkan menjadi data yang utuh. Pengumpulan data dilakukan untuk melaksanakan data dan informasi mengenai peningkatan keterampilan menulis puisi melalui model Concept Sentence. Dalam pengumpulan data ini dilakukan oleh peneliti. Pengumpulan data ini dilakukan sebelum melaksanakan penelitian di kelas 4B. Teknik pengumpulan data yang digunakan yaitu wawancara, observasi, dan tes.

\section{Instrumen Pengumpulan Data}

Instrumen yang digunakan selama penelitian yaitu lembar observasi , lembar wawancara dan tes keterampilan menulis puisi. Lembar observasi berupa lembar kinerja guru dan lembar aktivitas siswa mengenai pelaksanaan penelitian dengan menggunakan model Concept Sentence. Lembar wawancara untuk mendapatkan informasi data jumlah siswa, karakteristik siswa, dan bagaimana kendala yang sering dialami selama proses pembelajaran. Sedangkan tes keterampilan menulis puisi berupa lembar kerja menulis puisi. 
Teknik Analisis Data

Teknik analisis data yang digunakan saat proses penelitian adalah teknik kuantitatif deskriptif, karena terdapat analisis perbandingan antar siklus yang digunakan oleh peneliti. Terdapat dua siklus dalam penelitian ini. Siklus I terjadi karena hasil penelitian belum mengalani peningkatan yang telah ditentukan dari hasil pra siklus. Sedangkan siklus II merupakan penyempurnaan atau perbaikan dari hasil penelitian siklus I agar hasil semakin meningkat dan semakin lebih baik.

\section{Indikator Ketercapaian}

Nilai Kriteria Ketuntasan Minimal (KKM) bahasa Indonesia adalah 75. Adapun pada penelitian ini dikatakan berhasil apabila memperoleh peningkatan keterampilan menulis puisi siswa sudah mencapai $\geq 75 \%$, baik pada ketuntasan klasikal maupun peningkatan pada setiap indikator keterampilan menulis deskripsi siswa. Maka dari itu, Penelitian Tindakan Kelas ini dapat diberhentikan apabila hasil perolehan persentase telah sesuai dengan hasil yang telah ditentukan.

\section{C.Hasil Penelitian dan Pembahasan} Hasil penelitian yang dijelaskan adalah mengenai pelaksanaan tindakan pada setiap siklus, peningkatan keterampilan menulis puisi pada bahasa Indonesia menggunakan model Concept Sentence. Pada deskripsi hasil penelitian diperoleh dari data-data penelitian pada lembar observasi guru, lembar observasi siswa, soal tes siswa, serta dokumentasi berupa foto selama kegiatan penelitian. Pada penelitian ini, tindakan yang dilakukan yaitu sebanyak dua siklus. Dalam setiap siklus terdapat 1 pertemuan. Pelaksanaan siklus I pada tanggal 15 Oktober 2019, sedangkan pada siklus Il pada tanggal 22 Oktober 2019.

Adapun pengamatan kinerja guru pada siklus I dan siklus II menggunakan model Concept Sentence disajikan dalam tabel 4.1 sebagai berikut:

Tabel 1 Ketercapaian Indikator Kinerja Guru Siklus I dan Siklus II

\begin{tabular}{|c|c|c|c|c|c|}
\hline \multirow{2}{*}{ No } & Aspek & \multicolumn{2}{|c|}{ Siklus I } & \multicolumn{2}{c|}{ Siklus II } \\
\cline { 3 - 6 } & Nilai & Kategori & Nilai & $\begin{array}{c}\text { Katego } \\
\text { ri }\end{array}$ \\
\hline 1. & $\begin{array}{c}\text { Pendahul } \\
\text { uan }\end{array}$ & 80 & $\begin{array}{c}\text { Sangat } \\
\text { Baik }\end{array}$ & 100 & $\begin{array}{c}\text { Sangat } \\
\text { Baik }\end{array}$ \\
\hline 2. & $\begin{array}{c}\text { Pengelo } \\
\text { mpokkan }\end{array}$ & 67 & Baik & 93 & $\begin{array}{c}\text { Sangat } \\
\text { Baik }\end{array}$ \\
\hline 3. & $\begin{array}{c}\text { Pemberia } \\
\text { n kata } \\
\text { kunci }\end{array}$ & 70 & Baik & 100 & $\begin{array}{c}\text { Sangat } \\
\text { Baik }\end{array}$ \\
\hline 4. & $\begin{array}{c}\text { Berpikir } \\
\text { bersama }\end{array}$ & 67 & Baik & 93 & $\begin{array}{c}\text { Sangat } \\
\text { Baik }\end{array}$ \\
\hline 5. & $\begin{array}{c}\text { Kesimpul } \\
\text { an }\end{array}$ & 73 & Baik & 93 & $\begin{array}{c}\text { Sangat } \\
\text { Baik }\end{array}$ \\
\hline \multicolumn{2}{|c|}{ Rata-rata } & 71 & Baik & 86 & $\begin{array}{c}\text { Sangat } \\
\text { Baik }\end{array}$ \\
\hline \multicolumn{2}{|c|}{} \\
\hline
\end{tabular}


Hasil pengamatan kinerja guru pada tabel diatas dapat dideskripsikan sebagai berikut:

1) Pendahuluan

Pelaksanaan pembelajaran dimulai dengan siswa duduk dengan rapih di bangkunya, lalu guru meminta siswa memimpin doa, dan guru menyampaikan tujuan pembelajaran. Temuan pada siklus I guru belum cukup baik dalam mengkondisikan siswa dikelas dan belum menyampaikan tujuan pembelajaran dengan baik. Sedangkan temuan pada siklus II yaitu guru sudah cukup baik dalam menyampaikan tujuan pembelajaran.

2) Pengelompokkan

Tahap pengelompokkan ini yaitu pembagian siswa ke dalam 5 kelompok, menyampaikan kompetensi, dan menyampaikan materi. Temuan pada siklus ini penyampaian materi dan kompetensi belum baik sehingga membuat siswa kesulitan memahami materi. Sedangkan temuan pada siklus 2 adalah guru sudah baik dalam menyampaikan pengetahuan awal mengenai materi puisi.
3) Pemberian kata kunci

Pada tahap ini guru memberikan kata kunci kepada setiap kelompok sebagai bahan untuk membuat puisi. Temuan pada siklus I, guru belum memastikan siswa menggunakan kata kunci tersebut untuk pembuatan puisi. Sedangkan temuan pada siklus II adalah guru sudah baik saat memastikan bahwa siswa menggunakan kata kunci tersebut.

4) Berpikir bersama

Tahap ini guru memastikan setiap kelompok untuk aktif berdiskusi dengan anggota kelompoknya, dan tetap mengerjakan tugasnya secara mandiri. Temuan pada siklus 1 guru belum bisa memastikan siswa mengerjakan secara mandiri. Dan pada siklus II guru sudah bekeliling ke setiap kelompok dan memastikan siswa mengerjakannya secara mandiri.

5) Kesimpulan

Kegiatan ini guru memberikan penguatan terhadap kesimpulan pembelajaran yang siswa buat. Temuan pada siklus I ini guru belum memberikan penguatan yang baik, sedangkan pada siklus II guru sudah memberikan penguatan dengan baik. 
Hasil lembar observasi kinerja guru pada siklus I dan siklus II yang diperoleh dari dua pertemuan dengan hasil rata-rata ketercapaian indikator pada siklus I yaitu 71 yang termasuk ke dalam kategori baik, sedangkan pada siklus II yaitu 86 yang termasuk ke dalam kategori sangat baik.

Adapun pengamatan aktivitas siswa pada siklus I dan siklus II menggunakan model Concept Sentence disajikan dalam tabel 4.2 sebagai berikut:

Tabel 2 Ketercapaian Indikator Aktivitas Siswa Siklus I dan Siklus II

\begin{tabular}{|c|c|c|c|c|c|}
\hline No & Aspek & \multicolumn{2}{|c|}{ Siklus I } & \multicolumn{2}{c|}{ Siklus II } \\
\cline { 3 - 6 } & & Nilai & Kategori & Nilai & $\begin{array}{c}\text { Katego } \\
\text { ri }\end{array}$ \\
\hline 1. & $\begin{array}{c}\text { Pendahulua } \\
\mathrm{n}\end{array}$ & 71 & Baik & 90 & $\begin{array}{c}\text { Sangat } \\
\text { Baik }\end{array}$ \\
\hline 2. & $\begin{array}{c}\text { Pengelomp } \\
\text { okkan }\end{array}$ & 71 & Baik & 85 & $\begin{array}{c}\text { Sangat } \\
\text { Baik }\end{array}$ \\
\hline 3. & $\begin{array}{c}\text { Pemberian } \\
\text { kata kunci }\end{array}$ & 71 & Baik & 86 & $\begin{array}{c}\text { Sangat } \\
\text { Baik }\end{array}$ \\
\hline 4. & $\begin{array}{c}\text { Berpikir } \\
\text { bersama }\end{array}$ & 73 & Baik & 85 & $\begin{array}{c}\text { Sangat } \\
\text { Baik }\end{array}$ \\
\hline 5. & Kesimpulan & 73 & Baik & 84 & $\begin{array}{c}\text { Sangat } \\
\text { Baik }\end{array}$ \\
\hline \multicolumn{2}{|c|}{ Rata-rata } & 72 & Baik & 86 & $\begin{array}{c}\text { Sangat } \\
\text { Baik }\end{array}$ \\
\hline
\end{tabular}

1) Pendahuluan

$$
\begin{aligned}
& \text { Pelaksanaan pembelajaran } \\
& \text { dimulai dengan siswa duduk }
\end{aligned}
$$

dengan rapih di bangkunya, lalu siswa memimpin doa, dan menyimak penyampaian tujuan pembelajaran. Temuan pada siklus I siswa belum cukup baik dalam menyimak penyampaian tujuan pembelajaran oleh guru, dan masih ada yang tidak tertib saat berdoa. Sedangkan temuan pada siklus II yaitu siswa sudah baik dalam menyimak tujuan pembelajaran dan sudah tertib saat berdoa.

2) Pengelompokkan

Tahap pengelompokkan ini yaitu pembagian siswa ke dalam 5 kelompok, penyampaian kompetensi, dan materi. Temuan pada siklus ini siswa belum sepenuhnya menerima anggota kelompoknya, dan belum memahami materi dengan baik. Sedangkan temuan pada siklus 2 siswa sudah menerima teman kelompoknya dan sudah memahami materi dengan baik.

3) Pemberian kata kunci

Pada tahap ini siswa menerima kata kunci yang diberikan oleh guru sebagai bahan untuk membuat puisi. Temuan pada siklus I siswa belum menggunakan kata kunci sebagai bahan untuk menulis puisi. Sedangkan temuan pada siklus II 
siswa sudah menggunakan kata kunci tersebut.

4) Berpikir bersama

Temuan pada siklus 1 siswa belum aktif berdiskusi dengan teman kelompoknya dan belum mengerjakan tugas secara mandiri. Dan pada siklus II siswa sudah aktif berdiskusi dan mengerjakan tugasnya secara mandiri

5) Kesimpulan

Temuan pada siklus I ini siswa belum mampu membuat kesimpulan atas pembelajaran yang telah dilaksanakan, sedangkan pada siklus II sudah dapat memberikan kesimpulan dengan baik.

Hasil lembar observasi aktivitas siswa pada siklus I dan siklus II yang diperoleh dari dua pertemuan dengan hasil rata-rata ketercapaian indikator pada siklus I yaitu 72 yang termasuk ke dalam kategori baik, sedangkan pada siklus II yaitu 86 yang termasuk ke dalam kategori sangat baik.

Selain memaparkan aktivitas guru dan siswa, akan memaparkan mengenai keterampilan menulis puisi. Pencapaian pada penelitian dapat dilihat dari temuan dalam setiap indikator keterampilan menulis puisi pada pra siklus s/d siklus II. Berikut ini hasil tes menulis puisi dapat dilihat dalam diagram perbandingan setiap indikator pada gambar 1 :

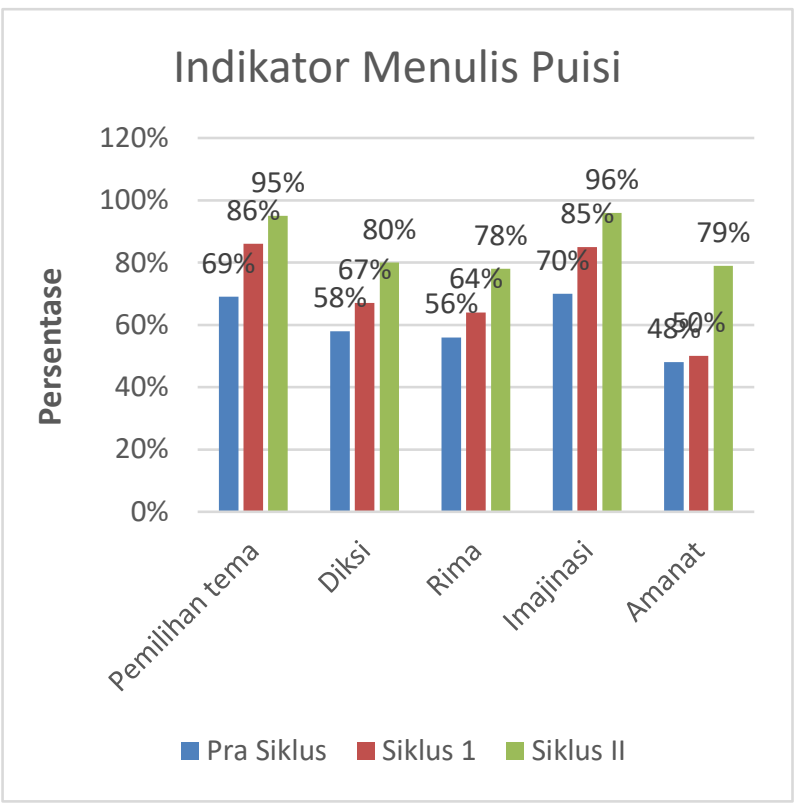

\section{Gambar 1 Diagram Perbandingan Keterampilan Menulis Puisi} Sumber: Hasil Pengolahan Data Tahun 2020

Hasil data pada gambar 1 maka dapat dilihat ketercapaian dari setiap indikator keterampilan menulis puisi siswa pada pra siklus-siklus II sudah menunjukkan peningkatan dari hasil sebelumnya. Siswa sudah tidak mengalami kesulitan pada setiap indikator menulis puisi yang mengakibatkan nilai yang diperoleh sudah memenuhi ketuntasan. Berikut ini deskripsi pada setiap indikator yaitu:

1) Pemilihan tema yang menarik 
Indikator pemilihan tema menunjukan rata-rata $95 \%$. Siswa sudah mampu memilih tema yang menarik untuk penulisan puisinya, menurut Solihah (2018:17) menyebutkan bahwa tema bersifat khusus pada setiap siswa atau bersifat objektif, artinya setiap siswa yang satu dan yang lain tidak akan sama. Hal ini dapat terlihat dari pemilihan tema sudah sangat menarik setiap siswanya.

2) Diksi

Indikator ini artinya siswa harus mampu memilih kata yang tepat sesuai tema yang mereka pilih. Rata-rata ketercapaian indikator ini yaitu $80 \%$. Pada indikator ini siswa sudah bisa memanfaatkan kata kunci dengan baik sehingga pemilihan kata yang dituangkan ke dalam puisinya sudah beragam.

3) Rima

Pada indikator ini memiliki ketercapaian $78 \%$, sudah mencapai ketuntasan yang diharapkan. Menurut Solihah (2018:18) rima adalah persamaan bunyi yang berulang dan teratur pada kata yang letaknnya berdekatan di dalam satu baris atau antar baris. Hal ini dapat dilihat pada hasil kerja siswa dimana persamaan bunyi sudah selaras pada antar barisnya.

4) Imajinasi

Menurut Nugiyantoro (dalam Solihah: 2018) bahwa cara membangkitkan minat siswa serta merangsang imajinasi yaitu dengan membawanya keluar kelas. Dan itu membantu untuk peningkatan pada indikator ini. Siswa sudah memiliki imajinasi yang bagus, dan terlihat pada tulisan puisi mereka.

5) Amanat

Pada indikator ini siswa sudah dapat memberikan pesan moral atau amanat pada puisinya. Menurut Solihah (2018) amanat adalah pesan atau nasihat yang didapat oleh pembaca melalui puisi yang dibacanya. Guru sebagai pembaca sudah dapat menemukannya dalam hasil kerja siswa.

Hasil tes menulis puisi siklus II mendapatkan persentase $84 \%$ dari jumlah siswa yang tuntas 24 siswa dari 28 orang siswa. Pada siklus II seluruh siswa sudah mengalami peningkatan dalam keterampilan menulis puisi. Sejumlah 24 orang telah memenuhi ketuntasan pada siklus II. Oleh karena itu, penelitian dihentikan karena hasil perolehan 
siswa sudah mencapai indikator ketercapaian yaitu $84 \%$ dari $75 \%$ secara klasikal.

\section{Kesimpulan}

Berdasarkan

pembahasan

penelitian dapat disimpulkan bahwa penerapan proses pembelajaran mengenai bahasa Indonesia khususnya menulis puisi telah dilakukan sesuai dengan langkahlangkah model Concept Sentence. Hasil pelaksanaan metode Concept Sentence dan observasi yang dilaksanakan oleh teman sejawat, bahwa pada siklus I hasil kinerja guru memperoleh nilai rata-rata sebesar 71 dan siklus II sebesar 86. Sedangkan nilai rata-rata aktivitas siswa dalam kegiatan proses pembelajaran guided writing pada siklus I sebesar 72 dan siklus II sebesar 86. Keterampilan menulis puisi siswa meningkat, setelah menerapkan model Concept Sentence dalam proses pembelajaran bahasa Indonesia. Jika dilihat dari ketercapaian indikator keterampilan menulis puisi siswa secara keseluruhan, bahwa keterampilan menulis puisi pada pra siklus yaitu $22 \%$, kemudian meningkat pada siklus 1 yaitu 50\% dan semakin meningkat pada siklus II yaitu 84\%. Dengan demikian, keterampilan menulis puisi siswa semakin meningkat dan berhasil dalam setiap siklus melalui penerapan model Concept Sentence dalam proses pembelajaran bahasa Indonesia.

\section{DAFTAR PUSTAKA}

Aqib, Z. dkk. (2011). Penelitian

Tindakan Kelas untuk SD,

SLB, dan TK. Bandung: Yrama Widya.

Aqib, Z. (2016). Penelitian Tindakan Kelas. Bandung: Penerbit CV Yrama Widya.

Djadjuri, D., Saepuloh, L. dan Rizal, S.U. (2015). Kurikulum dan Pembelajaran (Jilid 1 Kurikulum). Bekasi: Cv Nurani. Huda, Miftahul. (2014). Model-model Pengajaran dan Pembelajaran: Isu-isu dan Paradigmatis. Yogyakarta: Pustaka Pelajar. Mahsun. (2017). Metode Penelitian Bahasa. Depok: Rajawali Pers.

Padi, E. (2013). Kumpulan Super Lengkap Sastra Indonesia. Jakarta: Perpustakaan Nasional RI.

Solihah, L.(2018). "Peningkatan Keterampilan Menulis Puisi Melalui Pendekatan Kontekstual Di Kelas V SD 
Negeri Rancaloa Kota

Bandung “. Jurnal Cakrawala

Pendas Vol 4, No. 12018.

Suprijono, A. (2012). Cooperative

Learning: Teori dan Aplikasi

PAIKEM. Yogyakarta: Pustaka

Pelajar.

Wardoyo, S. M. (2013). Teknik Menulis Puisi Panduan Menulis Puisi untuk Siswa, Guru dan Dosen. Yogyakarta: Graha IImu. 